Provided for non-commercial research and education use. Not for reproduction, distribution or commercial use.

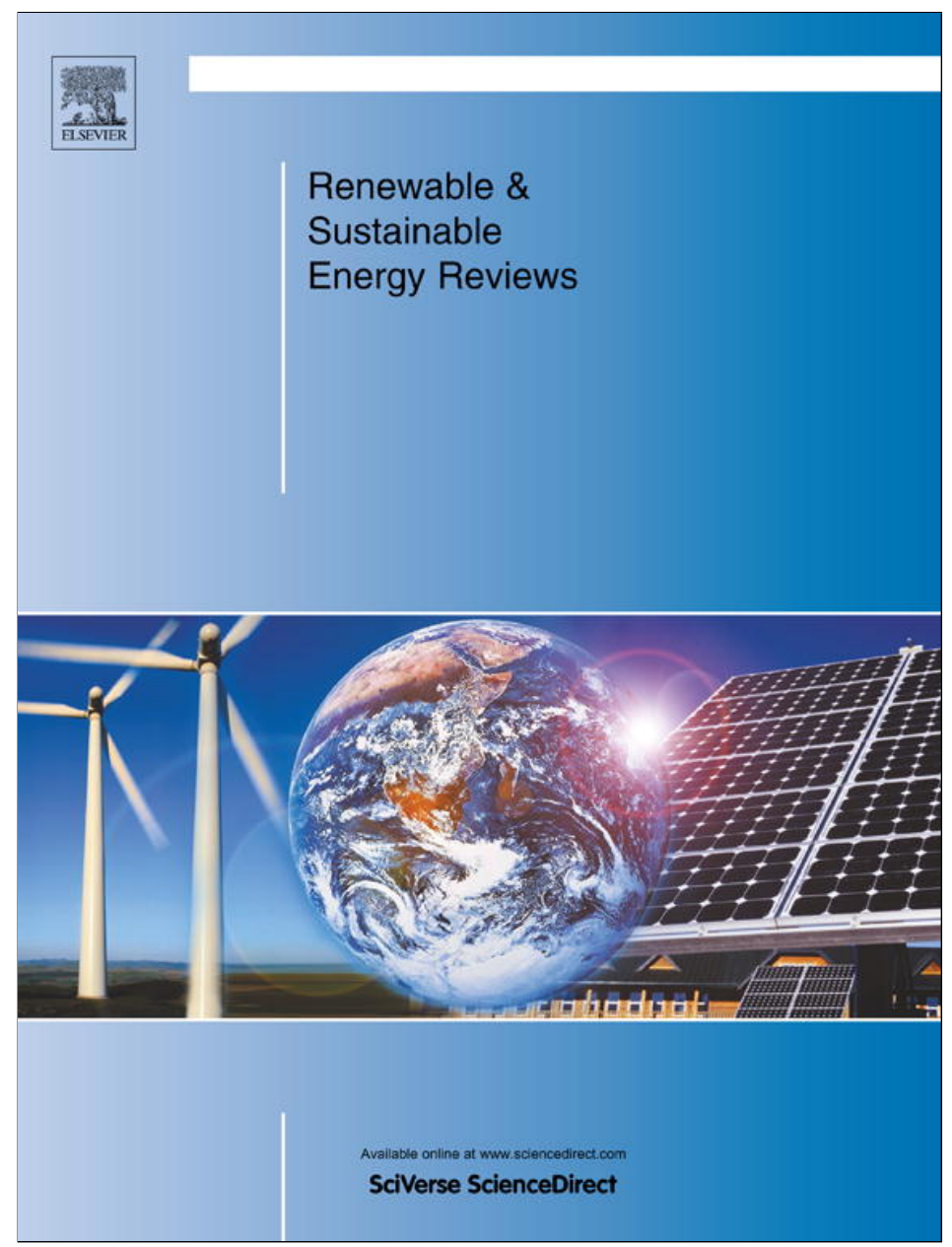

This article appeared in a journal published by Elsevier. The attached copy is furnished to the author for internal non-commercial research and education use, including for instruction at the authors institution and sharing with colleagues.

Other uses, including reproduction and distribution, or selling or licensing copies, or posting to personal, institutional or third party websites are prohibited.

In most cases authors are permitted to post their version of the article (e.g. in Word or Tex form) to their personal website or institutional repository. Authors requiring further information regarding Elsevier's archiving and manuscript policies are encouraged to visit:

http://www.elsevier.com/authorsrights 


\title{
Surveying techno-economic indicators of microalgae biofuel technologies
}

\author{
Lauro André Ribeiro ${ }^{\mathrm{a}, *}$, Patrícia Pereira da Silva ${ }^{\mathrm{b}, 1}$ \\ a School of Sciences and Technology, University of Coimbra and INESCC, R. Antero de Quental, 199, 3000-033 Coimbra, Portugal \\ ${ }^{\mathrm{b}}$ School of Economics, University of Coimbra and INESCC, Av. Dias da Silva, 165 Room 207 3004-512 Coimbra, Portugal
}

\section{A R T I C L E I N F O}

\section{Article history:}

Received 29 February 2012

Received in revised form

8 March 2013

Accepted 15 March 2013

\section{Keywords:}

Algae

Biofuels

Cost

Policies

Renewables

Emerging technologies

\begin{abstract}
A B S T R A C T
The need to develop innovative technologies that could replace fossil fuels and, consequently contribute to the reduction in emissions of greenhouse gases is now clear. In this circumstance, algal biofuels are generating considerable interest around the world. The purpose of this study is to provide an integrated assessment of microalgae potential as a source of biofuels, while comparing its costs with that from other emerging biofuel technologies. This article emphasizes the importance of emerging United States and European Union energy policies that will encourage the development of innovative, and sustainable technologies in their respective regions. An ample review of the scientific literature was carried out, contributing to the analysis of cost, economic and technical indicators. The results obtained allowed the detection of important gaps of information that need to be filled, in order to guide future investment decisions concerning this rising technology.
\end{abstract}

c) 2013 Elsevier Ltd. All rights reserved.

\section{Contents}

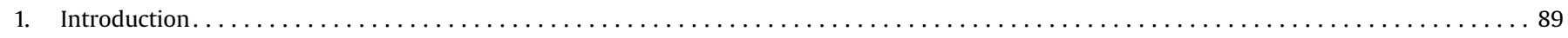

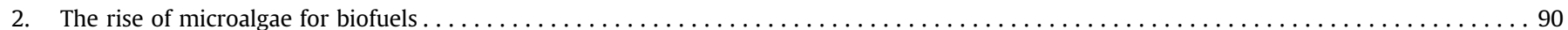

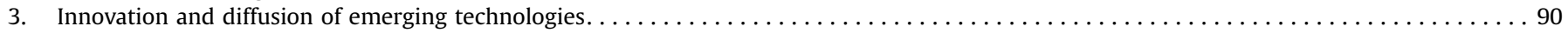

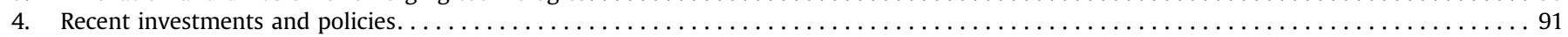

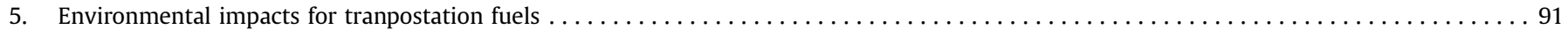

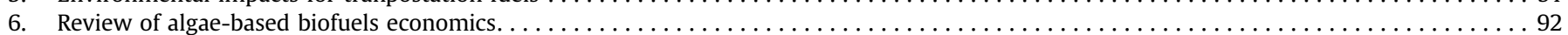

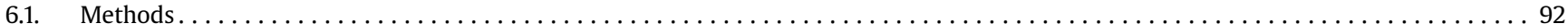

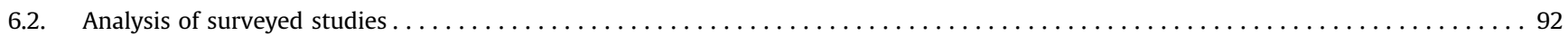

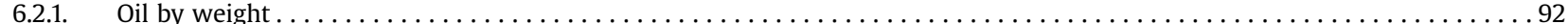

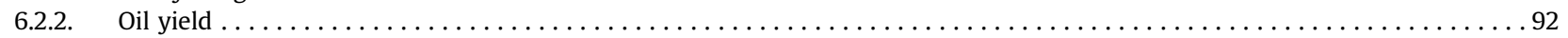

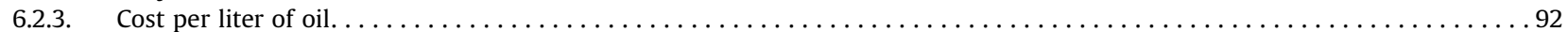

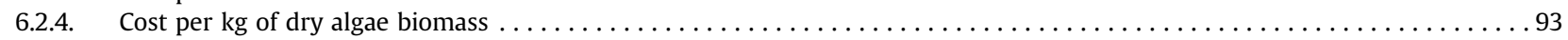

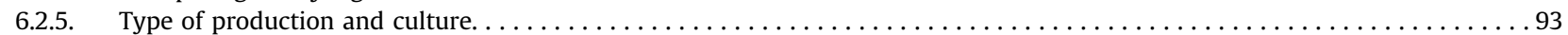

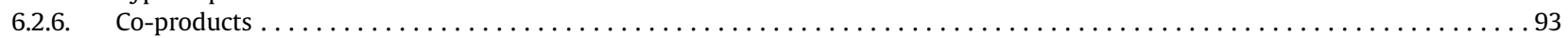

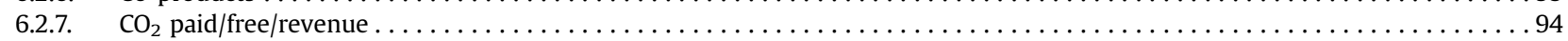

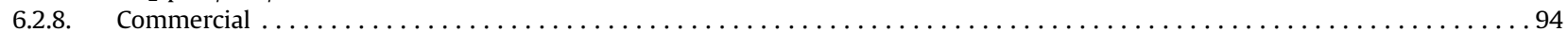

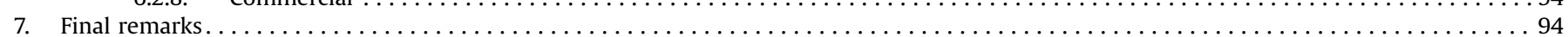

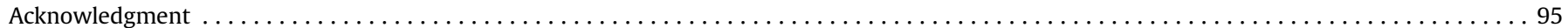

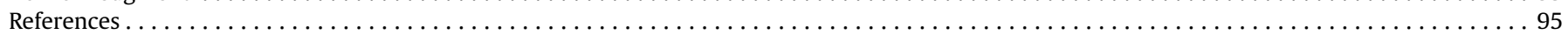

\footnotetext{
* Corresponding author. Tel.: +351917326212.

E-mail addresses: lribeiro@inescc.pt (L.A. Ribeiro), patsilva@fe.uc.pt (P.P.d. Silva).

${ }^{1}$ Tel.: +351239790 577.
}

\section{Introduction}

Emerging technologies hold great promise and high risk, being a challenge to determine which emerging technologies have the best chance of becoming industry changing and commercially successful. In this article we contribute with a comprehensive set of information that will be key for a deeper techno-economic 
analysis of next-generation biofuel technologies, with an original focus on microalgae.

Advanced biofuels are defined by the American Energy Independence and Security Act of 2007, as being "renewable fuels, other than ethanol derived from corn starch, that have lifecycle greenhouse gas emissions that achieve at least a 50 percent reduction over baseline lifecycle greenhouse gas emissions". They include cellulosic ethanol, biomass based biodiesel, and other unspecified types of biofuels other than conventional corn-based ethanol and vegetable oil-based biodiesel. In this article we are analyzing microalgae specificities, bringing evidence on current costs provided by different authors. This paper is structured as follows. In the first section, we provide a literature review on the ascending relevance of microalgae for biofuels. Secondly, we present a brief review of some theoretical ideas of innovation adoption and diffusion and it is followed by an overview of recent investments and policies in both United States and European Union. Subsequently, the research methodology is presented describing sample selection, used data analysis and scrutiny of results. At last, final remarks are drawn.

\section{The rise of microalgae for biofuels}

A set of articles can be found in the literature evidencing the technical feasibility of growing algae for biofuel production [1-17], in which the majority of them demonstrate the absence of the major drawbacks associated with current 1st generation biofuels. For example, the most common drawback pointed out of $1 \mathrm{st}$ generation biofuels as being the affect on food prices due to massive arable land use.

Microalgae are microscopic organisms that are found in both marine and freshwater. These organisms use solar energy to combine water with carbon dioxide $\left(\mathrm{CO}_{2}\right)$ to create biomass [9]. The mechanism of photosynthesis in microalgae is similar to higher plants, with the difference in efficiency, microalgae are capable of producing 30 times as much oil per unit of land area as compared to terrestrial oilseed [9]. This technology uses the oils from microalgae as the raw material to produce biofuel.

In autotrophic microalgae cultivation, carbon dioxide must be fed constantly during daylight hours. Algae biodiesel production can potentially use some of the carbon dioxide that is released in power plants by burning fossil fuels. This $\mathrm{CO}_{2}$ could be available at little or no cost [2]. However, the fixation of waste $\mathrm{CO}_{2}$ of other sorts of business could represent an important source of income to the algae industry. Although this is a very promising future possibility, and some species have proven to show themselves capable of using the flue gas as nutrients, there are few species that survive at high concentrations of $\mathrm{NO}_{x}$ and $\mathrm{SO}_{x}$ present in these gases [18].

The nutrients for the cultivation of microalgae (mainly nitrogen and phosphorus) can be obtained from liquid effluent wastewater (sewer); therefore, besides providing its growth environment, there is the potential possibility of waste effluents treatment $[19,20]$. This could be explored by microalgae farms as a source of income in a way that they could provide the treatment of public wastewater, and obtain the nutrients the algae need.

After the process of extracting the oil from algae, the resulting product can be converted to biodiesel. The biodiesel produced from algal oil has physical and chemical properties similar to diesel from petroleum, to biodiesel produced from crops of 1st generation and compares favorably with the International Biodiesel Standard for Vehicles (EN14214) [3].

Commercial algae production facilities employ both open and closed cultivation systems. Each of these has advantages and disadvantages, but both require high capital input. In the surveyed literature neither open ponds nor closed photobioreactors (hereafter PBR) seem to be mature technologies. Therefore, until largescale systems are built and operated over a number of years, many uncertainties will remain [21].

Like a refinery, it is still possible to obtain other products in the cultivation of microalgae, such as ethanol, methane and biohydrogen. The latter is being largely studied but still much work has to be done toward commercialization [22-25]. Therefore, they are possible proven processes in the laboratory, but still lack applied studies in industrial scale to become viable options.

As of today, it has been shown that it is scientifically and technically possible to derive the desired energy products from algae in the laboratory. The question lies, however, in whether it is a technology that merits the support and development to overcome existing scalability challenges and make it economically feasible [26]. Additionally, the basic economic motivation for biofuels is that they are a convenient, low-priced, domestically producible and a substitute for oil, an energy source that is getting costlier and it is mostly imported from politically volatile regions [27]. Economic feasibility is believed to be currently the main hurdle to overcome for this technology. Current costs associated to both the state of the science and technologies are sizeable and represent a main factor hampering development.

\section{Innovation and diffusion of emerging technologies}

High costs often prevent the market diffusion of novel and efficient energy technologies. As microalgae biofuel is not a mature technology, it becomes important to provide a revision of technological innovation and diffusion aspects to enlighten some available options that may help overpass the barriers found by innovative technologies.

It is widely recognized that modern economic analysis of technological innovation originates fundamentally from the work of Joseph Schumpeter [28], who stressed the existence of three necessary conditions for the successful deployment of a new technology: invention, innovation and diffusion. His seminal work has been constantly referred by many authors [29], and each of keywords represent different aspects, in particular: invention includes the conception of new ideas; innovation involves the development of new ideas into marketable products and processes; and diffusion, in which the new products and processes spread across the potential market.

Emergent technologies are relatively expensive at the point of market introduction but eventually become cheaper due to mechanisms such as learning-by-doing, technological innovation and/or optimization, and economies of scale. The combined effects of these mechanisms are commonly referred to as technological learning. Over the last decades, learning theories combination with evolutionary economics have led to the innovation systems theory that expands the analysis of technological innovation, covering the entire innovation system in which a technology is embedded. In particular, "An innovation system is thereby defined as the network of institutions and actors that directly affect rate and direction of technological change in society" [30].

In the emerging energy technologies field, there is a strong need to influence both the speed and the direction of the innovation and technological change. With that in mind, policymakers are putting their efforts on lowering the costs of renewable energy sources to support the development of renewable technologies, either through direct means such as government-sponsored research and development (R\&D), or by enacting policies that support the production of renewable technologies. It is well documented $[31,32]$ that both higher energy prices and changes 
in energy policies increase inventive activity on renewable energy technologies [33].

As noted by [33], the higher costs of renewable energy technologies suggest that policy intervention is necessary to encourage investment. Otherwise, in the lack of public policy favoring the development of renewable energy, production costs remain too high and they do not represent an option in replacing fossil fuels.

Policies to foster innovation should not only focus on the creation and supply of new technologies and innovations, but also on the diffusion and take-up of green innovations in the market place. Such policies need to be well designed to ensure that they support and do not distort the market formation, and should be aligned with competition policies and international commitments [34].

With this purpose, several government policies have been introduced in the energy markets worldwide in an effort to reduce costs and accelerate the market penetration of renewables. Although the effectiveness of alternative policies to encourage innovation still needs to be tested empirically, it is expected that these policies will stimulate innovation in renewable energy [35].

In Section 4, some of the policies that could enhance the development of microalgae biofuels are, therefore, revised.

\section{Recent investments and policies}

Impressive biofuel support policies have in recent times been adopted in both the United States (with projected production of 60 billion 1 of second-generation biofuel by 2022) and the European Union (with 10\% renewable energy in the transport sector by 2020). Due to the magnitude of the two markets and their sizeable biofuel imports, the U.S. and EU mandates could become an important driver for the global development of advanced biofuels, since current scenarios from the International Energy Agency (IEA) evidence a shortfall in domestic production in both the U.S. and EU that would need to be met with imports $[35,36]$.

Although algae biofuels are not yet fully competitive in the biofuel market, many venture capital firms had made recent investments in algae fuel ventures [37]. Accordingly, a set of policies to assist the development of microalgae technology is being created and constantly improved. These policy incentives aim at increasing renewable energy deployment, in latu sensu, and subsequently will promote development in the algae industry.

In this context, the U.S. Department of Energy published on May 2010 important information for the U.S. policy trends in the "National Algal Biofuels Technology Roadmap". This document represents the output of the National Algal Biofuels Workshop held in Maryland in 2008, and was intended to provide a comprehensive roadmap report that summarizes the state of algae biofuels technology and documents the techno-economic challenges that have to be met and taken into account before algal biofuel can be produced commercially.

Afterwards, the US Environmental Protection Agency (USEPA) suggested revisions to the National Renewable Fuel Standard program (RFS). The proposed changes intended to address changes to the RFS program as required by the Energy Independence and Security Act of 2007 (EISA). The revised statutory requirements establish new specific volume standards for cellulosic biofuel, biomass-based diesel, advanced biofuel, and total renewable fuel that must be used in transportation fuel each year. The regulatory requirements for RFS will apply to domestic and foreign producers, and importers of renewable fuel [37].

While cellulosic ethanol is expected to play a large role in meeting the 2007 American Energy Independence and Security Act (EISA) goals, a number of next generation biofuels show significant promise in helping to achieve the 21 billion gal goal.
Of these candidates, biofuels derived from algae, particularly microalgae, have the potential to help the U.S. meet the new Renewable Fuels Standard (RFS) while at the same time moving the nation ever closer to energy independence [35].

To accelerate the deployment of biofuels produced from algae, The American President Obama and The U.S. Secretary of Energy Steven Chu announced on May 5th, 2009, the investment of US $\$ 800$ millions on new research on biofuels in the American Recovery and Renewal Act (ARRA). This announcement included funds for the Department of Energy Biomass Program to invest in the research, development, and deployment of commercial algal biofuel processes [38]. The funding will focus on algal biofuels research and development to make it competitive with traditional fossil fuels as well as the creation of a smooth transition to advanced biofuels that use current infrastructure. These policy trends are aligned with the focus of the majority of the countries presented in our set of chosen papers (Table 2).

Meanwhile, in order to promote the use of energy from renewable sources, the European Parliament published on April 2009, the Directive 2009/28/EC, which establishes a common framework for the promotion of energy from renewable sources, as well as it, establishes sustainability criteria for biofuels and bioliquids [39].

By the end of 2010, a communication from the European Parliament has set the strategy for a competitive, sustainable and secure energy future by 2020 . The Strategic Energy Technology (SET) Plan sets out a medium term strategy valid across all sectors. Yet, development and demonstration projects for the main technologies (e.g. second generation biofuels) must be speeded up [36]. The European SET-Plan lists several energy technologies, which will be required to bring together economic growth and a vision of a decarbonized society. It states that advanced biofuels, namely microalgae, are supposed to play a significant role. EU energy policy aims to represents a green "new deal", which will hopefully enhance the competitiveness of EU industry in an increasingly carbon-constrained world. However, in our dataset it was possible to include only three European studies. In the forthcoming years it is expected a rise in the volume of European available data, due to both the strong European transport energy policy drivers and scenarios made available by the International Energy Agency (IEA) regarding Energy Technologies Perspectives 2010. In this sense, incentives and targets are to be met as well as the witnessing of a higher proliferation of pilot stage algae installations in this highly oil dependent continent.

\section{Environmental impacts for tranpostation fuels}

Among diverse crop types, biofuel production can be obtained from several sources, as some listed in Table 1. However, the environmental impacts of each crop type choice cannot be ignored and the same applies to land-use requirements.

Comparing to other biofuel feedstock sources, algae-based biofuels present several advantages. These advantages include: (a) capability of producing oil during all year long and with superior efficiency, therefore the oil productivity of microalgae is greater compared to the most efficient crops; (b) producing in brackish water and on not arable land [41]; not affecting food supply or the use of soil for other purposes [2]; (c) possessing a fast growing potential and several species have $20-50 \%$ of oil content by weight of dry biomass [2]; (d) Regarding air quality, production of microalgae biomass can fix carbon dioxide [2]; (e) nutrients for its cultivation (nitrogen and phosphorous, mainly) can be obtained from sewage, therefore there is a possibility to assist the municipal wastewater treatment [19,20]; (f) growing algae do not require the use of herbicides or pesticides [42]; 
Table 1

Comparison of biofuel feedstock environmental impacts for transportation fuels (adapted from [40]).

\begin{tabular}{|c|c|c|c|c|c|c|c|c|}
\hline Crop Type & & Corn & Sugar cane & Switch grass & $\begin{array}{l}\text { Wood } \\
\text { residue }\end{array}$ & Soybeans & $\begin{array}{l}\text { Rapeseed, } \\
\text { Canola }\end{array}$ & Algae \\
\hline \multirow{4}{*}{$\begin{array}{l}\text { Use of resources } \\
\text { during } \\
\text { growing, } \\
\text { harvesting and } \\
\text { refining of fuel }\end{array}$} & Water & High & High & Med-Low & Med & High & High & Med \\
\hline & Fertilizer & High & High & Low & Low & Low-Med & Med & Low \\
\hline & Pesticide & High & Med & Low & Low & Med & Med & Low \\
\hline & Energy & High & Med & Low & Low & Med-Low & Med-Low & High \\
\hline \multicolumn{2}{|c|}{$\begin{array}{l}\mathrm{GHG}^{\mathrm{G}} \text { emissions }{ }^{\mathrm{a}}\left(\mathrm{kg} \text { of } \mathrm{CO}_{2}\right. \\
\text { per mega joule of energy } \\
\text { produced) }\end{array}$} & $81-85$ & $4-12$ & -24 & $\mathrm{~N} / \mathrm{A}$ & 49 & 37 & -183 \\
\hline \multicolumn{2}{|c|}{$\begin{array}{l}\text { Opportunities and } \\
\text { challenges }\end{array}$} & $\begin{array}{l}\text { Technology ready } \\
\text { and relatively } \\
\text { cheap; reduces } \\
\text { food supply. }\end{array}$ & $\begin{array}{l}\text { Technology ready; } \\
\text { limited as to where it } \\
\text { will grow; reduces } \\
\text { food supply. }\end{array}$ & $\begin{array}{l}\text { It will not } \\
\text { compete with } \\
\text { food crops; } \\
\text { technology not } \\
\text { ready. }\end{array}$ & $\begin{array}{l}\text { Technology } \\
\text { ready; } \\
\text { reduces } \\
\text { food supply. }\end{array}$ & $\begin{array}{l}\text { Technology } \\
\text { ready; } \\
\text { reduces } \\
\text { food supply. }\end{array}$ & $\begin{array}{l}\text { Technology } \\
\text { ready; } \\
\text { reduces } \\
\text { food supply. }\end{array}$ & $\begin{array}{l}\text { Potential for huge production } \\
\text { levels and it will not compete } \\
\text { with food crops; technology not } \\
\text { fully ready for scale up. }\end{array}$ \\
\hline
\end{tabular}

a Emissions produced during the growing, harvesting, refining and burning. Gasoline is 94, diesel is 83.

(g) algae can also produce valuable co-products, as proteins and biomass after oil extraction, that can be used as animal feed, medicines or fertilizers $[3,10]$, or fermented to produce ethanol or methane [5]; (h) biochemical composition of algal biomass can be modulated by different growth conditions, so the oil yield can be significantly improved [43]; and (i) Capability of performing the photobiological production of "biohydrogen" [22-25,44].

Compared to other biofuel technologies, the most favorable factors for the cultivation of microalgae for the production of biofuels is that they can be grown in brackish (salt) water, on nonfertile land and the oil yield production is far superior.

Although there is a possibility for microalgae to turn into an important source of biofuels, many challenges may halt the development of algae-based biofuels to become commercially viable. Based on literature, the most important are: (a) The selection of species must balance the requirements for biofuel production and extraction of valuable by-products [6]; (b) There are few commercial cultivating "farms", so there is a lack of data on large-scale cultivation [7]; (c) Impossibility of introducing flue gas at high concentrations, due to the presence of toxic compounds such as $\mathrm{NO}_{\mathrm{x}}$ and $\mathrm{SO}_{\mathrm{x}}$ [16]; (d) Choosing algae strains that require fresh water to grow can be unsustainable for operations on a large scale and exacerbate fresh water scarcity [21]; and (e) the price is still too high to compete with fossil fuels.

In order to mitigate issues concerning the economical side of algae biofuels, a review of algae-based biofuels costs was made and it is detailed in Section 6 of this article.

\section{Review of algae-based biofuels economics}

\subsection{Methods}

This section presents the main findings from a comprehensive literature review carried out on algae-based biofuels production costs throughout the world. The search was conducted with a focus on available scientific papers to gather studies that have been published during the last 2 decades containing detailed information on the methodology, assumptions and data used. The selected studies main results are summarized in Table 2. The selected papers were the ones that shared common characteristics, namely providing simultaneous information about the 9 elected costs and technical specific indicators. Several other articles, although equally relevant, were withdrawn from our sample because they did not comply with our current data systematization and others were excluded due to lack of transparency or sufficient quantitative information. It is also important to notice that not all studies present the cost of production in the same manner. Some present the costs of producing algal biomass and others the costs of producing oil, as illustrated in Table 2 . For some surveyed studies, the original outcomes were further calculated to express the results in dollars, $\mathrm{kg}$ and liters. A dataset was built with the above-mentioned methodology and comprised specific cost related indexes, presented and analyzed in the next section. We believe this to be a novel and useful addition to the field of economics of microalgae.

\subsection{Analysis of surveyed studies}

\subsubsection{Oil by weight}

Microalgae produce storage lipids in the form of triacylglycerols (TAGs). The percentage of lipids is strongly dependent depending on the species or on how the cultivation process is made, as many microalgae species can be induced to accumulate substantial quantities of lipids. In this study, not all reviewed studies expressed the percentage of oil by weight of biomass, but analyzing those that provide these numbers, it is clear the wide range of values that can be achieved. The percentages of oil by weight varied from $10 \%$ to $60 \%$ and there was not a clear correlation between price and oil by weight in the selected studies.

\subsubsection{Oil yield}

Similarly, there were verified significant variations among oil yields from different authors. This was an expected outcome due to the utilization of different species and cultivating techniques. In spite of being an expected result, it is an important data for comparing species, techniques and costs among the studies, for example to select the more adequate species for cultivation. On the other hand, these comparisons have to be made carefully, due to different units that the results are represented.

\subsubsection{Cost per liter of oil}

This item is one of the main issues of algae biofuel nowadays, if not the most important one. Every effort is being made to reduce this figure, so that algae biofuel can be more competitive and can be a viable alternative in of transportation fuels market. The data vary widely from study to study, with conclusions stating that it is economically feasible or impossible to be competitive. The prices shown are not normalized for today prices, as they represent what authors found at that point of time. The economical feasibility of microalgae is one of the main drawbacks of this technology for producing biofuels. Algal biodiesel has to be cheap to compete 
Table 2

Published costs for algal biomass and biodiesel production: relevant data, processes and key results.

\begin{tabular}{|c|c|c|c|c|c|c|c|c|c|c|c|}
\hline Authors & Year & $\begin{array}{l}\text { Oil by } \\
\text { weight }\end{array}$ & Oil yield & $\begin{array}{l}\text { Cost per } \\
\text { liter of oil } \\
\left(\mathrm{L}^{-1}\right)\end{array}$ & $\begin{array}{l}\text { Cost per Kg of } \\
\text { dry biomass } \\
\left(\mathrm{kg}^{-1}\right)\end{array}$ & $\begin{array}{l}\text { Type of } \\
\text { production }\end{array}$ & Culture & $\begin{array}{l}\text { Co- } \\
\text { products }\end{array}$ & $\begin{array}{l}\mathrm{CO}_{2} \text { paid/ } \\
\text { free/ } \\
\text { revenue }\end{array}$ & Commercial & Country \\
\hline $\begin{array}{l}\text { Gladue and } \\
\text { Maxey [45] }\end{array}$ & 1994 & $50 \%$ & 20 g. $\mathrm{L}^{-1} \mathrm{~d}^{-1}$ & NM & $\$ 12$ & Fermentor & N. alba & No & NM & No & USA \\
\hline $\begin{array}{l}\text { Benemann } \\
\text { and Oswald } \\
{[46]}\end{array}$ & 1996 & $50 \%$ & $30 \mathrm{~g} \mathrm{~m}^{-2} \mathrm{~d}^{-1}$ & $\$ 0.43$ & $\$ 0.24$ & Open & NM & Yes & Paid & Yes & USA \\
\hline $\begin{array}{l}\text { Sheehan et al. } \\
{[9]}\end{array}$ & 1998 & $40 \%$ & $67,5 \mathrm{mt} / \mathrm{ha} / \mathrm{yr}$ & $\$ 0.63-1.01$ & NM & Open & NM & No & Paid & No & USA \\
\hline Lee [47] & 2001 & NM & $25 \mathrm{~g} \mathrm{~m}^{-2} \mathrm{~d}^{-1}$ & NM & $\$ 8-15$ & Open & NM & No & NM & Yes & Singapure \\
\hline $\begin{array}{l}\text { Benemann } \\
\text { et al. [48] }\end{array}$ & 2002 & $\mathrm{NM}$ & $33 \mathrm{~g} \mathrm{~m}^{-2} \mathrm{~d}^{-1}$ & NM & $\$ 0.1$ & Open & NM & No & Free & No & USA \\
\hline $\begin{array}{l}\text { Molina Grima } \\
\text { et al. [49] }\end{array}$ & 2003 & $10 \%$ & $1.25 \mathrm{~kg} \mathrm{~m}^{-3} \mathrm{~d}^{-1}$ & NM & $\$ 32.16$ & PBR & Phaeodactyum & No & Paid & No & Spain \\
\hline Behrens [50] & 2005 & NM & $5.8 \mathrm{~g} \mathrm{~L}^{-1} \mathrm{~d}^{-1}$ & NM & $\$ 2.01$ & Fermentor & NM & No & NM & Yes & USA \\
\hline $\begin{array}{l}\text { Moheimani } \\
\text { [51] }\end{array}$ & 2005 & $33 \%$ & $0.54 \mathrm{~g} \mathrm{~L}^{-1} \mathrm{~d}^{-1}$ & NM & $\$ 7.55-14.56$ & $\begin{array}{l}\text { Open and } \\
\text { PBR }\end{array}$ & $\begin{array}{l}5 \text { species of } \\
\text { coccolithophorids }\end{array}$ & Yes & Paid & No & Australia \\
\hline $\begin{array}{l}\text { Harmelen } \\
\text { and Oonk } \\
{[52]}\end{array}$ & 2006 & $30 \%$ & $27 \mathrm{~g} \mathrm{~m}^{-2} \mathrm{~d}^{-1}$ & $\$ 1.06$ & $\$ 0.29$ & Open & NM & Yes & Free & No & Netherlands \\
\hline Chisti [2] & 2007 & $30 \%$ & $\begin{array}{l}72 \text { and } 32 \mathrm{~g} . \\
\mathrm{m}^{-2} \mathrm{~d}^{-1}\end{array}$ & $\begin{array}{l}\$ 1.41 \text { and } \\
\$ 1.81\end{array}$ & $\$ 0.47$ and $\$ 0.60$ & $\begin{array}{l}\text { PBR and } \\
\text { Open }\end{array}$ & NM & No & Free & No & New Zeland \\
\hline Dmitrov [53] & 2007 & $15-25 \%$ & $\begin{array}{l}0.14-0.33 \mathrm{~L} / \mathrm{m}^{2} / \\
\mathrm{yr}\end{array}$ & $\$ 5.38$ & NM & PBR & NM & Yes & Free & No & USA \\
\hline $\begin{array}{l}\mathbf{L i}, \mathbf{X u} \text { and } \mathbf{W u} \\
{[54]}\end{array}$ & 2007 & $44-48 \%$ & $\begin{array}{l}12.8- \\
15.5 \mathrm{~L}^{-1} \mathrm{~d}^{-1}\end{array}$ & $\$ 2.40$ & NM & Fermentor & $\begin{array}{l}\text { Chlorella } \\
\text { protothecoides }\end{array}$ & No & NM & No & China \\
\hline $\begin{array}{l}\text { Alabi, } \\
\text { Tampier } \\
\text { and Bibeau } \\
{[55]}\end{array}$ & 2009 & $\begin{array}{l}15 \% \\
25 \% \text { and } \\
50 \%\end{array}$ & $\begin{array}{l}9.38 \\
15.3 \mathrm{~g} \mathrm{~m}^{-2} \mathrm{~d}^{-1} \\
\text { and } 50 \mathrm{~g} \mathrm{~L}^{-1}\end{array}$ & $\begin{array}{l}\$ 14.44 \text {, } \\
\$ 24.60 \text { and } \\
\$ 2.68\end{array}$ & $\begin{array}{l}\$ 2.66, \$ 7.32 \text { and } \\
\$ 1.54\end{array}$ & $\begin{array}{l}\text { Open, PBR } \\
\text { and } \\
\text { Fermentor }\end{array}$ & NM & Yes & Free & No & Canada \\
\hline Pate [56] & 2009 & Vary & Vary & $\begin{array}{l}\$ 2.38-4.49 \\
\text { and } \$ 5.28- \\
10.30\end{array}$ & Vary & $\begin{array}{l}\text { PBR and } \\
\text { Open }\end{array}$ & NM & No & Vary & Vary & USA \\
\hline $\begin{array}{l}\text { Williams and } \\
\text { Laurens } \\
{[57]}\end{array}$ & 2010 & $15-50 \%$ & $\begin{array}{l}18- \\
37 \mathrm{~g} \mathrm{~m}^{-2} \mathrm{~d}^{-1}\end{array}$ & $\$ 0.79-3.08$ & $\$ 0.36-\$ 0.65$ & $\begin{array}{l}\text { Hybrid } \\
\text { Open/PBR }\end{array}$ & NM & Yes & Free & No & UK \\
\hline $\begin{array}{l}\text { Davis, Aden } \\
\text { and } \\
\text { Pienkos } \\
{[58]}\end{array}$ & 2011 & $25 \%$ & $\begin{array}{l}25 \mathrm{~g} \mathrm{~m}^{-2} \mathrm{~d}^{-1} \\
\text { and } \\
1.25 \mathrm{~kg} \mathrm{~m}^{-3} \mathrm{~d}^{-1}\end{array}$ & $\begin{array}{l}\$ 2.25 \text { and } \\
\$ 4.78\end{array}$ & NM & $\begin{array}{l}\text { Open and } \\
\text { PBR }\end{array}$ & NM & No & Paid & No & USA \\
\hline
\end{tabular}

NM: Not mentioned.

*For conversion, a barrel was calculated as $159 \mathrm{l}$, a US gallon $3.78 \mathrm{l}$ and currency conversions are: $\$$ Aus $/ \$$ US $=1.03$ and $€ / \$$ US $=1.4$.

with other biofuels and also with the currently dominant fossil fuels. Algal biodiesel has to be cheap to compete as a significant source of energy. According to [2], for algal biodiesel to potentially replace fossil fuels, it must be priced as follows: $C_{\text {algal oil (per }}$ liter $\leq 6.9 \times 10^{-3} \times C_{\text {Petroleum (per barrel). }}$. For example, if crude oil is priced at US $\$ 107 / \mathrm{bbl}$ (price on February 28th, 2012) algal biodiesel must be priced lesser than US\$0.74/L to offer a competitive alternative. Given the long-term uptrend in crude oil prices, the real competitive price level for algal biodiesel can be far higher and it could be nearer than predicted, although it is impossible to predict when that will happen.

\subsubsection{Cost per kg of dry algae biomass}

The cost per kg of dry algae biomass is an alternative measure for evaluating the economically feasibility of this technology, as it is the raw material from where the oils are going to be extracted. Likewise to the cost per liter of oil, there were verified significant variations among different studies, depending on the processes and procedures used to obtain it.

\subsubsection{Type of production and culture}

The types of production found were open ponds, photobioreactors (PBRs) and using fermentors. Concerning the various algal species and strains, they vary from study to study, depending on location and culture techniques. For that reason it is not yet possible to predict what species or strain will be the best suited for commercial biofuel production, but it is most likely that it will differ from case to case, depending on the location, cultivation techniques chosen, processing technologies available, nutrients source, local climacteric conditions, among other potential factors.

\subsubsection{Co-products}

Many of the authors refer the possibility of commercializing coproducts generated in the production of algae biofuels. As stated before, algae can also produce valuable co-products, such as proteins, natural colorants, and biomass after oil extraction, that can be used as animal feed, medicines or fertilizers $[3,10]$, or fermented to produce ethanol, methane or other biofuels [5]. Although this possibility is widely reported, just a few studies $[46,51-53,55,57]$ looked with attention to this question and made financial calculations on the feasibility of producing biofuel and co-products together. This could be a promising opportunity to make algae biofuel more economically feasible. With the production of many products in algae cultivation (as it is done in a petrochemical refinery for fossil), technical and in particular economical efficiency can arise in the joint production of two or more products. If the cost of producing two products by one firm is 
less than the cost of producing the same two products by two firms, the production process exhibits economies of scope [59]. Thus, it is expected a reduction in price of algae biofuels in the coming years if this approach is followed. Yet, when producing other co-products such as protein in conjunction with substantial amounts of biofuels, it is a potential threat the saturation of potential markets, due to the large amounts produced [53].

\subsection{7. $\mathrm{CO}_{2}$ paid/free/revenue}

The input of $\mathrm{CO}_{2}$ needed for most of the processes could be provided for free, with no financial counterpart, it could be bought (paid) or, some company that produces a considerable amount of $\mathrm{CO}_{2}$ could pay the algae biofuel producer to process this $\mathrm{CO}_{2}$. So far, this last option is just a possibility for future financial calculations, as all the studies surveyed or accounted $\mathrm{CO}_{2}$ for free or paid for this gas. The existing and future carbon markets, coupled with more stringent limits of the emissions, may lead to companies increasingly paying to dispose off of their $\mathrm{CO}_{2}$ emissions, and this may represent a reduction in the productions costs, resulting in lower microalgae fuel prices.

\subsubsection{Commercial}

Most of the studies available in the open literature are based on small-scale laboratory experiments, not commercial facilities already selling algae biomass and/or biofuels. As most of the algae biofuel production so far was made in experimental facilities with low capacity of fuel production, and with many companies expanding their facilities, it is expected that this will lead to economies of scale, now that production is increasing and average costs of cultivating algae are falling (and marginal costs are below average cost) [55]. In this context, it is also expected that the efficiency of such companies rise. In this regard it is possible to differentiate "technical efficiency" and "economical efficiency". Technical efficiency implies that the maximum output has been produced with a given set of inputs, giving that the most adequate technologies and processes are used. Economical efficiency implies that the maximum output has been produced at a given (opportunity) cost, or that a minimum (opportunity) cost has been achieved for a given level of output [55]. With a large set of alternatives of inputs and outputs within a developing market such as the algae one, it can be complex and hard to achieve the technical and economical efficiency in the near future, but as the time goes by and the technology matures, better trends in production will arise.

The sample of surveyed results was displayed chronologically, in order to assess the existence of any type of progress in the indicators values over a time frame of almost 20 years. However, there is no obvious evolution in the outcomes along the years, what reinforces the need for more research focused in the economical aspects of microalgae production. Few cost estimates are also available, what justifies the apparent shortness of our database. However, it can conclude that to reach commercial viability, costs will need to be substantially reduced. Given the early stage of this technology and its rapid development, cost reductions may indeed be possible.

It is interesting to remark that only three papers have a focus on the European country, albeit being one of the biggest energy dependent continents in the world regarding oil consumption for transports. Therefore, this perception calls for an understanding of each country, or region, energy policy framework towards fostering renewables deployment for transport, what is briefly presented in Section 4.

\section{Final remarks}

Biofuels play a vital role in meeting the energy needs of human beings. There is reason to believe they will continue to do so in the future albeit in a different manner. The basic economic motivation for biofuels is that they are a convenient, low-priced, domestically producible and a substitute for oil. In the presented survey it became clear that algae are now being intensively researched as a potential biofuel feedstock. In addition to their potentially high yields per unit land area, algae can grow in unsuitable land for agriculture, including industrial areas. Thus, their exploitation offers the possibility of a feedstock for producing biofuel that avoids damage to ecosystems and competition with agriculture associated with other biomass resources. Although many testing and start-up companies are in operation in several countries, cost information is scarce. Along the aforementioned literature review, a consensus was found that biofuels from algae are, in any case, are still at the research and development stage and face numerous obstacles related to energy and water needs, and productivity.

Consequently, we revisited the recent developments in biofuel algae-based markets and their economic and environmental impacts. From a research and technology perspective, we stressed the importance of the US bio-energy policies and the European SET-Plan, as well as by the scenarios from IAE in 2010. These policies inform that several countries have introduced mandates and targets for biofuel expansion and, moreover, that production, international trade and investment have increased sharply in the last few years.

The introduction of these new policies is essential for lowering the costs of algae biofuels, encourage investment and develop greater diffusion of this emergent technology. Otherwise, in the lack of public policy, currently production costs remain higher to replace fossil fuels. In the same manner, it is expected that these policies will stimulate innovation to tackle some of the problems in this emerging market.

The problems concerning large-scale production of biodiesel from algal farms on non-arable land include inconsistent and insufficient algal productivities, uncertain capital and operating costs, volatile market prices and unknown levels of government support. Our survey permits to conclude that although intensive work is being done on many technological issues, economic studies and respective data are scattered, incomplete and divergent. Also, this paper provided both, a chronological perspective and an updated analysis of the production and economic conditions that are certainly going to have a profound effect on the success of this important alternative fuel production process. From our assembly of nine elected indicators, cost per liter of oil clearly appears to be a key determinant for eventual market success, in spite of the discrepancy of its proposed values and no clear trend of findings over time.

With the onset of new policies, incentives and massive investment in the private and public spheres, more researchers are forging new understanding in the science required to make algal biofuels economically feasible.

By assessing the costs of different algae cultivation techniques, it is apparent that the current economic situation standpoint towards large-scale production of algae biodiesel has not yet seemed to be viable as a solution to displace petroleum-based fuels. In the present situation, the technology to efficiently produce biodiesel from microalgae is not competitive with more advanced and emerging renewable technologies. However, with policy support and incentives, we believe that the algal biofuel industry will continue to develop and assuming that this technology follows renewable energy cost trends, costs will decrease to eventual economic viability. In parallel, processes must be developed to reduce costs and increase production. In this respect, the currently fast rate of development of algae biofuel technology and the actual rising of petroleum-based fuels prices are encouraging algae-based biofuels feasibility in the next few years.

Although our work does not bring an exhaustive review, our approach and filtering methodology embodies an innovative appraisal on significant works concerning the economic cost impacts of algae 
biofuels. And more importantly, complete and reliable published economic or cost related data are scarce, revealing a gap in research that we hope further contributions like this will help overcome.

\section{Acknowledgment}

This work has been partially supported by FCT under project grant PEst-C/EEI/UI0308/2011 and has been framed under the Energy for Sustainability Initiative of the University of Coimbra and supported by the R\&D Project EMSURE Energy and Mobility for Sustainable Regions (CENTRO 070224 FEDER 002004). The authors would like to acknowledge as well the Brazilian National Council for the Improvement of Higher Education (CAPES) for the financial support of Lauro André Ribeiro PhD grant.

\section{References}

[1] Tao L, Aden A. The economics of current and future biofuels. In Vitro Cellular \& Developmental Biology-Plant 2009;45:199-217.

[2] Chisti Y. Biodiesel from Microalgae. Biotechnology Advances 2007;25: 294-306.

[3] Brennan L, Owende P. Biofuels from microalgae-a review of technologies for production, processing, and extractions of biofuels and co-products. Renewable \& Sustainable Energy Reviews 2010;14:557-77.

[4] Carvalho AP, Meireles LA, Malcata FX. Microalgal Reactors: a review of enclosed system designs and performances. Biotechnology Progress 2006;22:1490-506.

[5] Hirano A, Ueda R, Hirayama S, Ogushi Y. $\mathrm{CO}_{2}$ fixation and ethanol production with microalgal photosynthesis and intracellular anaerobic fermentation. Energy 1997;22:137-42.

[6] Ono E, Cuello JL. Feasibility assessment of microalgal carbon dioxide sequestration technology with photobioreactor and solar collector. Biosystems Engineering 2006;95:597-606.

[7] Pulz O. Photobioreactors: production systems for phototrophic microorganisms. Applied Microbiology and Biotechnology 2001;57:287-93.

[8] Pulz O, Gross W. Valuable products from biotechnology of microalgae. Applied Microbiology and Biotechnology 2004;65:635-48.

[9] Sheehan J, Dunahay T, Benemann J, Roessler PA. Look back at the US department of energy's aquatic species program: biodiesel from algae, NREL/ TP-580-24190. USA: National Renewable Energy Laboratory; 1998.

[10] Spolaore P, Joannis-Cassan C, Duran E, Isambert A. Commercial applications of microalgae. Journal of Bioscience and Bioengineering 2006;101:87-96.

[11] Terry KL, Raymond LP. System design for the autotrophic production of microalgae. Enzyme and Microbial Technology 1985;7:474-87.

[12] Ugwu CU, Aoyagi H, Uchiyama H. Photobioreactors for mass cultivation of algae. Bioresource Technology 2008;99:4021-8.

[13] Amaro HM, Guedes AC, Malcata FX. Advances and perspectives in using microalgae to produce biodiesel. Applied Energy 2011;88:3402-10.

[14] Chisti Y, Yan J. Energy from algae: current status and future trends algal biofuels-a status report. Applied Energy 2011;88:3277-9.

[15] Demirbas MF. Biofuels from algae for sustainable development. Applied Energy 2011;88:3473-80.

[16] Chakrabarti MH, Ali M, Usmani JN, Khan NA, Hasan DB, Islam MS, et al. Status of biodiesel research and development in Pakistan. Renewable and Sustainable Energy Reviews 2012;16:4396-405.

[17] Alam F, Date A, Rasjidin R, Mobin S, Moria H, Baqui A. Biofuel from algae-is it a viable alternative? Procedia Engineering 2012;49:221-7.

[18] Brown LM. Uptake of carbon dioxide from flue gas by microalgae. Energy Conversion and Management 1996;37:1363-7.

[19] Cantrell KB, Ducey T, Ro KS, Hunt PG. Livestock waste-to-bioenergy generation opportunities. Bioresource Technology 2008;99:7941-53.

[20] Wang T, Yabar H, Higano Y. Perspective assessment of algae-based biofuel production using recycled nutrient sources: the case of Japan. Bioresource Technology 2013;128:688-96.

[21] Pienkos PT, Darzins A. The promise and challenges of microalgal-derived biofuels. Biofuels, Bioproducts and Biorefinering 2009;3:431-40.

[22] Saleem M, Chakrabarti MH, Raman AAA, Hasan DB, Daud WMAW, Mustafa A. Hydrogen production by Chlamydomonas reinhardtii in a two-stage process with and without illumination at alkaline $\mathrm{pH}$. International Journal of Hydrogen Energy 2012;37:4930-4.

[23] Rashid N, Lee K, Mahmood Q. Bio-hydrogen production by Chlorella vulgaris under diverse photoperiods. Bioresource Technology 2011;102:2101-4.

[24] Nobre BP, Villalobos F, Barragán BE, Oliveira AC, Batista AP, Marques PASS, Mendes RL, Sovová H, Palavra AF, Gouveia, L. Biorefinery from nannochloropsis sp. microalga-extraction of microalgal oils and pigments and biohydrogen production from the leftover biomass. Bioresource Technology, 2013 May;135:128-36. http://dx.doi.org/10.1016/j.biortech.2012.11.084. Epub 2012 Nov 28.
[25] Ferreira AF, Marques AC, Batista AP, PASS Marques, Gouveia L, Silva CM. Biological hydrogen production by Anabaena sp.-yield, energy and $\mathrm{CO}_{2}$ analysis including fermentative biomass recovery. International Journal of Hydrogen Energy 2012;37:179-90.

[26] Mcgraw L. The ethics of adoption and development of algae-based biofuels. Bangkok: UNESCO; 2009.

[27] Castanheira E, Silva PP. Governance of the emerging biofuel markets in European Union: the Portuguese context. Global Business and Economics Review 2010;12:230-51.

[28] Schumpeter JA. The theory of economic development: an inquiry into profits, capital, credit, interest, and the business cycle. Cambridge: Harvard University Press; 1934

[29] Söderholm P, Klaassen G. Wind power in europe: a simultaneous innovationdiffusion Model. Environmental and Resource Economics 2007;36:163-90.

[30] Junginger HM, Lako P, Lensink S, van Sark WGJHM, Weiss M. Technological learning in the energy sector. Netherlands: ECN, Group Science, Technology and Society, Copernicus Institute, Utrecht University Utrecht; 2008.

[31] Johnstone N, Hascic I, Popp D. Renewable energy policies and technological innovation: evidence based on patent counts. Environmental and Resource Economics 2010;45:133-55.

[32] Popp D. Induced innovation and energy prices. American Economic Review 2002;92:160-80.

[33] Popp D, Hascic I, Medhi N. Technology and the diffusion of renewable energy. Energy Economics 2011;33:648-62.

[34] OECD. Fostering Innovation for Green Growth. OECD Green Growth Studies, OECD Publishing [internet]. [cited 2011 Dec. 4] Available from: http://dx.doi. org/10.1787/9789264119925-en.

[35] U.S. Department of Energy, Office of energy efficiency and renewable energy, Biomass Program, National Algal Biofuels Technology Roadmap; 2010.

[36] Communication from The Commission to The European Parliament, The Council, The European Economic and Social Committee and The Committee Of The Regions of December 10th, 2010, Energy 2020: A strategy for competitive, sustainable and secure energy. Council of The European Union, Brussels; 2010.

[37] Oligae Report: Academic Edition [internet]. [cited 2010 Nov. 23] Available from: $\langle$ http://www.oligae.com/ $\rangle$.

[38] U.S. Environmental Protection Agency [internet]. [cited 2011 March 15] Available from:/http://www.epa.gov/OMS/renewablefuels/420f09023.htm).

[39] Directive 2009/28/EC of The European Parliament and of the Council of April 23rd, 2009 on the promotion of the use of energy from renewable sources and amending and subsequently repealing Directives 2001/77/EC and 2003/30/EC, Council of The European Union, Brussels; 2009.

[40] Groom MJ, Gray EM, Townsend PA. Biofuels and Biodiversity: Principles for creating better policies for biofuel production. Conservation Biology 2008;22:602-9.

[41] Searchinger T, Heimlich R, Houghton RA, Dong F, Elobeid A, Fabiosa J, et al. Use of U.S. croplands for biofuels increases greenhouse gases through emissions from land-use change. Science 2008;319:1238-40.

[42] Rodolfi L, Zittelli GC, Bassi N, Padovani G, Biondi N, Bonini G, et al. Microalgae for oil: strain selection, induction of lipid synthesis and outdoor mass cultivation in a low-cost photobioreactor. Biotechnology and Bioengineering 2008;102:100-12.

[43] Qin J. Bio-hydrocarbons from algae: impacts of temperature, light and salinity on algae growth. Barton, Australia: Rural Industries Research and Development Corporation; 2005 Feb.

[44] Ghirardi ML, Zhang L, Lee JW, Flynn T, Seibert M, Greenbaum E, et al. Microalgae: a green source of renewable $\mathrm{H}_{2}$. Trends in Biotechnology 2000;18:506-11.

[45] Gladue RM, Maxey JE. Microalgae feeds for aquaculture. Journal of Applied Phycology 1994;6:131-41.

[46] Benemann JR, Oswald WJ. Systems and economic analysis of microalgae ponds for conversion of $\mathrm{CO}_{2}$ to biomass. Final report to the Department of Energy, Pittsburgh Energy Technology Center, DOE/PC/93204-T5;1996.

[47] Lee YK. Microalgal mass culture systems and methods: their limitation and potential. Journal of Applied Phycology 2001;13:307-15.

[48] Benemann JR, Van Olst JC, Massingill MJ, Weissman JC, Brune DE. The controlled eutrophication process: using microalgae for $\mathrm{CO}_{2}$ utilization and agricultural fertilizer recycling [internet]. [cited $2011 \mathrm{Dec} 7]$. Available from: 〈http://www.csupomona.edu/ biodiesel/ref/algae_salton_sea.pdf〉.

[49] Molina Grima E, Belarbi EH, Acien Fernández F, Robles Medina A, Chisti Y. Recovery of microalgal biomass and metabolites: process options and economics. Biotechnology Advances 2003;20:491-515.

[50] Behrens PW. Photobioreactors and fermentors: The light and dark sides of growing algae. In: Andersen RA, editor. Algal culturing techniques. New York: Elsevier Academic Press; 2005. p. 189-204.

[51] Moheimani NR. The culture of coccolithophorid algae for carbon dioxide bioremediation [dissertation]. Australia: Murdoch University; 2005.

[52] van Harmelen T, Oonk H. Microalgae Biofixation Processes: Application and Potential Contributions to Greenhouse Gas Mitigation Options. Appeldoorn, Netherlands: TNO Built Environment and Geosciences; 2006.

[53] Dmitrov K. Greenfuel technologies: a case study for industrial photosynthetic energy capture [internet]. Brisbane, Australia; 2007 [cited 2011 apr 27]. Available from: 〈http://moritz.botany.ut.ee/ olli/b/Dmitrov.pdf $\rangle$. 
[54] Li X, Xu H, Wu Q. Large-scale biodiesel production from microalga Chlorella protothecoides through heterotrophic cultivation in bioreactors. Biotechnology and Bioengineering 2007;98:764-71.

[55] Alabi AO, Tampier M, Bibeau E. Microalgae technologies and processes fo biofuels/bioenergy production in British Columbia: current technology, suitability and barriers to implementation: Final Report. Victoria, British Columbia: British Columbia Innovation Council; 2009.

[56] Pate R. Techno-economics, siting, and resource use challenges for onshore algal biofuel production. In: Proceedings of Wind, Sea and Algae: International
Workshop on Offshore Algae for Biofuels and Beyond; 2009 April 20-22; Maribo, Denmark; 2009.

[57] Williams PJB, L.M.L. Laurens. Microalgae as a biodiesel \& biomass feedstocks: review \& analysis of the biochemistry, energetics \& economics. Energy and Environmental Science 2010;3:554-90

[58] Davis R, Aden A, Pienkos PT. Techno-economic analysis of autotrophic microalgae for fuel production. Applied Energy 2011;88:3524-31.

[59] Rothwell G. Electricity economics: regulation and deregulation. New Jersey: IEEE Press; 2000. 